\title{
A ROMA ÉS INDIAI POPULÁCIÓK GENETIKAI HASONLÓSÁGA ÉS ENNEK JELENTŐSÉGE A CSONTVELŐ DONOR REGISZTEREK ÖSSZETÉTELÉBEN
}

\section{GENETIC SIMILARITY BETWEEN THE GIPSY AND INDIAN POPULATIONS AND ITS IMPORTANCE IN THE COMPOSITION OF BONE MARROW DONOR REGISTRIES}

\author{
Petrányi Győző \\ az MTA rendes tagja, MD, tudományos tanácsadó, \\ Semmelweis Egyetem Általános Orvosi Kar 2. sz. Szülészeti és Nőgyógyászati Klinika \\ pg13@t-online.hu
}

\section{ÖSSZEFOGLALÁS}

\begin{abstract}
A közlemény összefoglalja a roma populációk jellegzetességeit, az etnikum genetikai sajátságait és ezek kapcsolódását az egyes betegségekkel szembeni fogékonyság és rezisztencia tulajdonságokkal. Magyar és indiai közös kutatás vizsgálta a roma etnikum HLA (Human Leucocyte Antigen) fenotípusait, és feltárta, hogy annak összetétele jelentősen eltér a világ más populációinál találttól, és csak az ősi indiai lakosságéhoz hasonló. Egy népességen belül az egyedek HLA-fenotípus hasonlósága vagy eltérése fontos a szerv- és szövettranszplantációkban. A csontvelő-átültetés során a donor és recipiens HLA antigénjeinek egyezése a legfontosabb feltétele a gyógyulásnak. Az ilyen donor megtalálása a családon belül is csak ritka esetekben lehetséges, ezért alakították ki minden országban, régióban a Nemzeti, majd a Világ Csontvelő Donor Regisztereket (WBMDR), melyeket HLA-antigénekre tipizált önkéntes donorok milliói képeznek. Mivel a roma népesség az egyik genetikailag (HLA) legeltérőbb etnikum, minimális az esély, hogy az őssejt-transzplantáció esetében megfelelő donort találjanak. Egy európai kutatási program (NAS-MADO) keretében a roma populációs HLA-antigének jellemzése mellett hatszáz roma donort toboroztak a Magyar Csontvelő Donor Regiszterbe. Ennek jelentőségét az igazolta, hogy már az első időkben sikerült roma beteg számára donort találni a hazai regiszterben, mely nem volt lehetséges a nagy WBMDR-ből. A romák egészségügyi, szociális és kulturális felzárkóztatásának kiemelkedő példájaként hívják fel a figyelmet a másfél évszázaddal ezelőtt tevékenykedő József főherceg aktivitására, aki alcsúti birtokán megvalósította a cigányság beilleszkedéséhez szükséges feltételeket.
\end{abstract}

\section{ABSTRACT}

This paper summarises the characteristics of gypsy population and their genetic features with the association of the resistance and susceptibility of diseases. The joint research of Hungarian and Indian institutions studied the HLA (Human Leucocyte Antigen) phenotypes of the gypsy 
population, and revealed that their HLA antigen composition is quite different from any other population of the world and is similar to the ancient Indian inhabitants. The HLA phenotypic characteristic of a population concerning the differences or similarity between the individuals is important in the activity of tissue and organ transplantation. In case of bone marrow (stem cell) transplantation the HLA compatibility between the donor and recipient is the most important prerequisite of the recovery. To find the HLA compatible donor in the family is unsuccessful in many cases, therefore Bone Marrow Donor Banks/Registries were established in many countries, and fused to a general World Bone Marrow Donor Bank (WBMDR) including millions of HLA typed voluntary donors. Since the gypsies as an ethnic group were found with one of the rarest HLA genetic the possibility is minimal to find compatible donor in case of stem cell transplantation. In the frame of a European research program, the NAS-MADO, besides the determination of HLA characteristics of the gypsies, 600 gypsy donors were recruited in the Hungarian Bone Marrow Donor Registry. The importance of this activity was proved during the very first period of the project, as it was possible to find a HLA compatible donor for a gypsy patient in the Hungarian Registry which was not possible from the big WBMDR. An excellent example of upward mobility of the gypsies was performed by Archduke Joseph Karl of Austria in his Alcsút estate in Hungary 150 years ago, where he carried out steps developing the social and health care conditions for the integration of the local gypsy population.

Kulcsszavak: cigányság genetikája, csontvelő-átültetés, HLA, csontvelő donor regiszterek

Keywords: genetic of gypsies, bone marrow transplantation, $\mathrm{HLA}$, bone marrow donor registries

\section{BEVEZETÉS}

Magyarország lakossága az ország történelme során más nemzetiségü, etnikumú populációkkal keveredett a honfoglalás, a kalandozások, a tatár, török háborúk, a Monarchia, a világháborúk eseményei következtében. A hazai lakosság nemzetiségi, etnikai összetételére vonatkozóan a 2011 évben végzett felmérés ezt jól tükrözi. A statisztikai adatok szerint a leggyakoribb populációk száma a következő volt. A 8,3 millió magyar mellett 315000 cigány, 185000 német, 29000 szlovák, 26000 román, 23000 horvát származású lakos és még egyéb kisebbség 1-7000 fős létszámban élt az országban. Ezért érthető, hogy a roma populációra különös figyelmet kell fordítani, szociális, kulturális, mentális, beilleszkedési és demográfiai vonatkozásokban (URL1). Egészségügyi szempontból kiemelt figyelmet érdemelnek a roma etnikum genetikai sajátságai és ezek kapcsolódásai egyes betegségekkel szembeni fogékonyság és rezisztencia tulajdonságokkal (Kiszely, 2004). Mivel a roma népesség az egyik genetikailag legeltérőbb etnikum hazánkban, fontos a romák HLA-antigénjeinek jellemzése, és annak kutatása, hogy ennek milyen hatása van az egészségügyi állapotukra. Tekintettel arra, hogy még ma is élnek elöítéletek mind a magyar, mind a cigány 
közösségekben, a kutatási cél megvalósítása emberi hozzáállást, körültekintést és megértést igényelt. A vizsgálatok nem mellőzhetik a cigányság szociális és egészségügyi helyzetének, illetve a beilleszkedésükhöz szükséges feltételeknek felmérését sem.

\section{A CIGÁNYOK EREDETE, CSOPORTJAI ÉS TULAJDONSÁGAI}

A cigányság őshazája Indiában volt Pandzsáb, Radzsasztán és Gudzsarát régiókban. Az indiai eredetet a nyelvi gyökerek, a szociális szerkezet, a betegség- és immunreaktivitási közös tulajdonságok és a genetikai hasonlóság támasztja alá. Indiából a cigányság balkáni területekre vándorolt, majd az 1400-as években jutott el Magyarországra, ahol nagy részük letelepedett. Az országon belüli egyenetlen regionális eloszlást a 1 . ábra mutatja be, melyen a meghatározott százalékos arányt is feltüntettük. A cigányságot általánosságban jellegzetes szociális hierarchia, erős családi és törzsi kapcsolat jellemzi. A népesség csoportjait és nyelvi jellemzését az alábbiakban foglalhatjuk össze (URL2).

Magyar cigányok: a magyarországi romák többsége, kb. kétharmada magyar anyanyelvü. Csoportjuk a kárpáti cigányoktól, a hagyományos magyarországi ci-

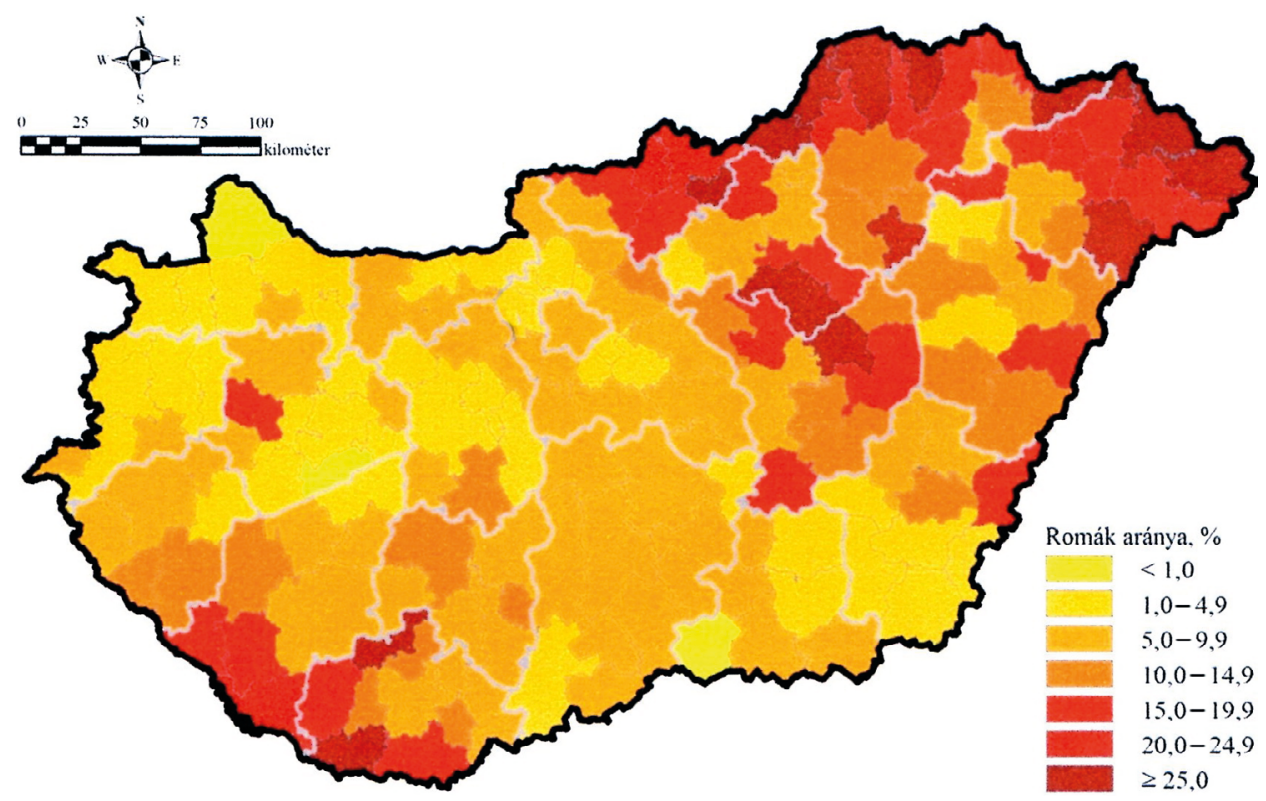

1. ábra. A cigányság országon belüli megoszlása

(Pénzes et al., 2018) 
gányoktól (roma nyelvű romungrók) származik. Foglalkozásukat tekintve zenészek, régiségkereskedők.

Oláhcigányok: történeti és nyelvi rokonság alapján meghatározott összefoglaló név. Nem egységesek, tíz-tizenkét egymástól kulturálisan és nyelvjárásváltozás szerint is elkülönülő csoportjuk van (lovárik, csurárik, kelderások). Ezek a csoportok hagyományosan egy-egy mesterség müvelöit is jelentették. Például a lovárik a magyarországi lókereskedelemmel foglalkoztak, és főként a Dunántúlon, a Duna-Tisza-közén tartózkodtak. A másári cigányok három nagyobb közössége Gyöngyösön és környékén, Pest és Heves megyében, valamint Hajdú-Bihar és Békés megyében él, és általában bádogossággal és késélezéssel foglalkozik.

Beások: anyanyelvük a román archaikus román dialektussal (erdélyiek). Önmagukat beásnak vagy cigánynak nevezik. A roma megjelölést általában elutasítják. Fő foglalkozásuk a famegmunkálás (fakanál-, teknő- stb. készítés). Árgyelánok (erdélyiek), nyelvjárásuk sajátosságai tekintetében a bánsági románnak megfelelö. Muncsánok (hegyvidékiek), nyelvjárásuk eredete tisztázatlan. Ticsánok (Tisza vidékiek), nyelvjárásuk nyugat-erdélyi, ún. krisán román dialektus.

Demográfiai jellegzetességük nagymértékben eltér a magyar lakosságétól, melyet a korfák tükröznek a legjobban (2. ábra). Ez jól magyarázza, hogy a cigány népesség száma gyorsan nőtt az 1900-as évek elejétől napjainkig (KSH, 2015). Így feltehető, hogy a cigányok két-három generáció múlva az ország lakosságának $20-30 \%$-át is képezhetik, nem is szólva egyes régiókról, ahol az arányuk $50 \%$ feletti is lehet.

Cigány korfa

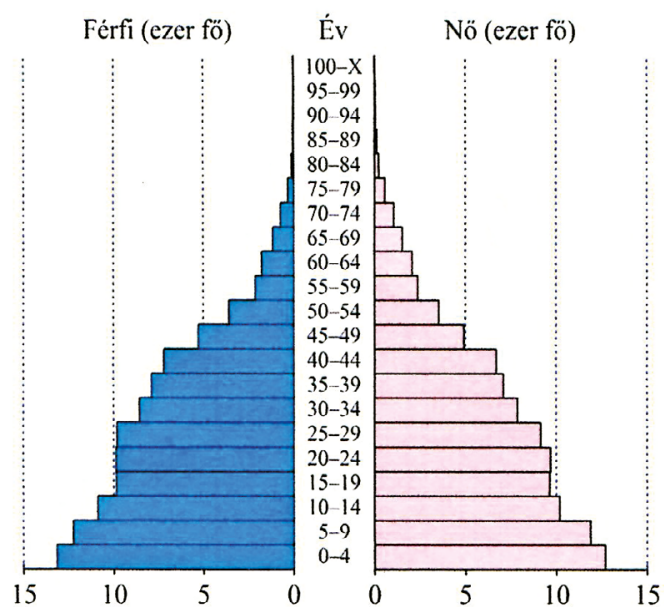

Magyar korfa

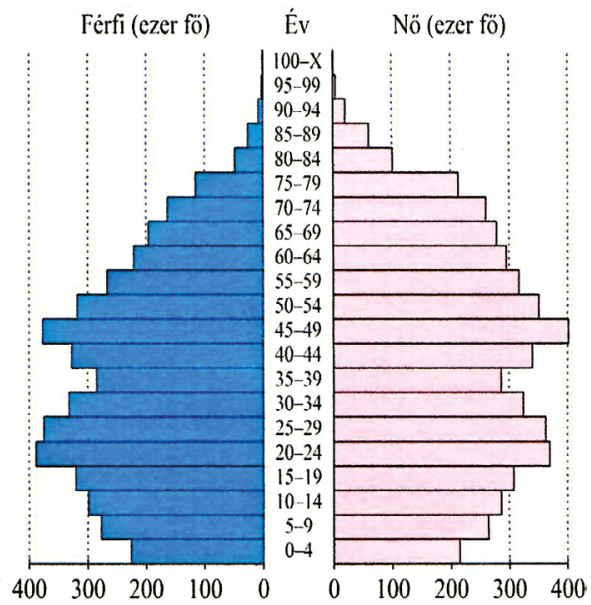

2. ábra. A cigányok és magyarok korfája (KSH, 2015) 


\section{A CIGÁNYOK GENETIKAI SAJÁTSÁGAI ÉS HLA POLIMORFIZMUSÁNAK JELLEGZETESSÉGEI}

A hazai roma populációról ismert, hogy több hullámban érkeztek Magyarországra, és különböző területeken telepedtek le. Az oláhcigányokat Nyíregyházán, a beás cigányokat pedig a Baranya megyei Alsószentmártonban vizsgálták, amely településen csak romák élnek. Kiszely 2004-ben megjelent könyvében kiemeli, hogy a felnőttkori laktózintolerancia, azaz tejcukoremésztési képtelenség a hazai roma lakosság 55,8 százalékában fordul elő, míg a magyar nem roma lakosság 36,6 százalékában. Halmozottabban fordul elő a romákban a veleszületett zöld hályog, szürke hályog, a policisztás vese domináns formája és az anyagcsere-rendellenességeket és az izomrendszert érintő több genetikai betegség. A klasszikus genetikai markerek közül négy izoenzim előfordulási gyakoriságában jelentős különbség van az oláh- és a beás cigányok között. Feltehetö, hogy a beás és az oláhcigány populációk között már olyan mérvü a genetikai különbség, hogy az a betegségspektrumuk és a genetikai betegségek gyakorisági eltéréseiben is megnyilvánul. A romák gyakoribb genetikai betegségeinek oka a cigányok 2-20\%-a közötti rokonházasság, vagyis a nagyobb beltenyésztettség.

A cigányok genetikai jellemzéséhez fontos vizsgálni a HLA- (Human Leucocyte Antigen) génkomplexen belüli sajátságokat. Ez a géncsalád határozza meg a szöveti antigének polimorfizmusát és az ahhoz kapcsolódó betegségfogékonyság és -rezisztencia géneket, valamint az immunrendszer elemeinek müködését. Ez a génkomplex biztosítja a biológiai diverzitást és az egyedek genetikai sokszínüségét (Petrányi-Gyódi, 2005).

Felmerült a kérdés, hogy ez a polimorf rendszer vajon visel-e olyan lenyomatot, mely alátámasztja a cigányok indiai eredetét. Az indiai-magyar, többéves tudományos együttmüködés keretében ezres nagyságrendü indiai egyén és több száz cigány személy HLA-tipizálásának eredménye adhatta meg erre a kérdésre a választ. A HLA-allélgyakoriság összehasonlítása során a roma és indiai személyekben a HLA-A 02 allél azonos gyakoriságát találták, mely a világon egyedülálló hasonlóság. Továbbá a HLA-A 0211 allél a világ egyetlenegy populációjában sem található meg ( $0 \%$ ), míg az indiaiakban 38\%-ban és a romákban 18\%-ban (Rajczi et al., 2001) van jelen. A HLA-rendszerhez kötött betegségkapcsoltságban is ki lehetett mutatni hasonlóságot a roma és az indiai populációkban. Ez a legkifejezettebben a szklerózis multiplex betegségben (SMS) volt megfigyelhetö, mely mindkét etnikai csoportban nagyon ritka. A magyar és roma népesség összehasonlító vizsgálata során ezt a megfigyelést jól lehetett demonstrálni. A HLA-B 7 allél (mely az SMS-betegséggel asszociált) a cigányoknál nem fordul elö, és ennek megfelelően a betegség gyakorisága is igen alacsony 2/100 000-hez, míg a magyaroknál ennek az allélnek a gyakorisága az egészségesekben $15 \%$, szemben az SMS-betegek 32\%-ával, akiknél a betegség előfordulása 37/100 000-hez (Gyódi et al., 1981). 


\section{CIGÁNYOK ESÉLYEI A CSONTVELŐ-ÁTÜLTETÉSRE}

A csontvelö-átültetés egyes rosszindulatú hematológiai betegségek, mint példádul a fehérvérüség (leukémiák) bizonyos formáiban az egyedüli lehetőség a gyógyulásra. A gyermekkorban és a fiatalkorban a magas gyakorisággal előforduló leukémiák csak olyan nagy dózisú kemoterápiás kezeléssel vagy teljestest-besugárzással gyógyíthatók, melyek mellékhatása a vérképző- és immunrendszert is elpusztítja. Ennek kivédése történik a csontvelőőssejt-átültetéssel. Az őssejtek családtagoktól vagy idegen donoroktól, illetve az úgynevezett csontvelő donor bankokból (regiszterekből BMDR) nyerhetők. A gyógyulási esély csak abban az esetben várható, ha az össejtdonor és a beteg HLA típusa azonos, ugyanis ebben az esetben fogadja be a beteg szervezet az idegen sejteket, és nem támadják meg a beadott sejtek a befogadó beteg szöveteit. Ebből is látható, hogy a csontvelö-átültetés sikerének alapvető feltétele a megfelelö, vagyis HLA-azonos donor biztosítása. A családi donor vagy ikertestvér szerencsés esetben egy olyan személy, aki az apától és az anyától ugyanazokat a haplotípusokat örökölte (3. ábra).

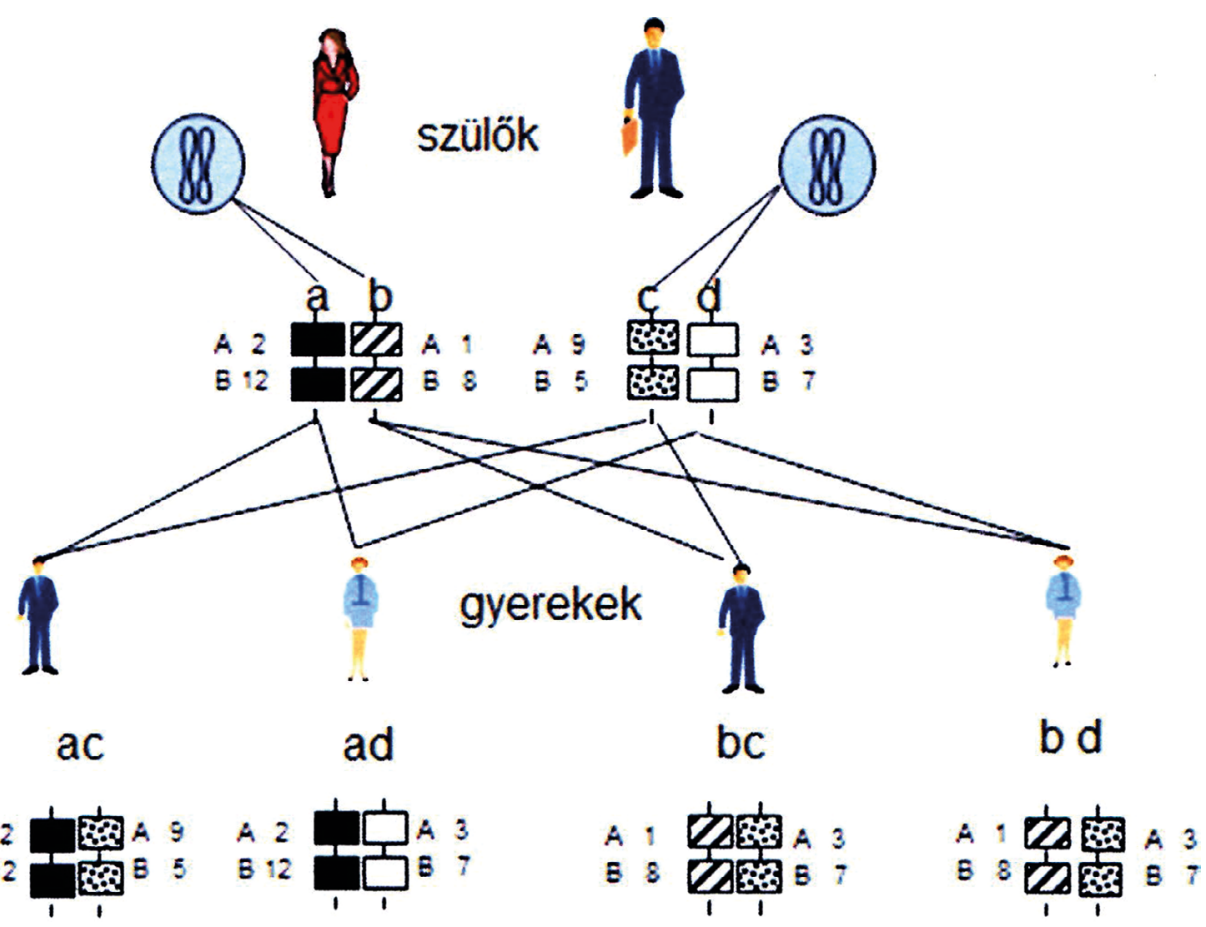

3. ábra. A szülői HLA-haplotípusok öröklődési variációi a gyermekekben (saját szerkesztés) 
Az idegen megfelelő donor a Magyar Csontvelö Donor Regiszterben (HBMDR) vagy valamelyik Nemzetközi, illetve Világregiszterben található (BMDRW) (Gahrton et al., 2003). Amennyiben a beteg HLA-típusa ritka, a megfelelő donor keresése hosszas és bonyolult folyamat, és sok esetben nem is eredményes. Ma már a regiszterek számítógépes összeköttetése és a keresés, valamint a talált donor elérése és vizsgálata automatikusan történik. A megfelelö, de külföldi donortól levett őssejt tárolása és szállítása technikailag megoldott, ami fontos az életképes össejtek beültetéséhez. A magyarországi cigány gyerekek között, különösen azokban a régiókban, ahol a cigány lakosság nagy számban él, a leukémiás betegség gyakoribb, mint a magyar populációban. Ezekben az esetekben a csontvelö-átültetéssel tervezett kezelések során már korán tapasztalták, hogy nem lehetséges megfelelő idegen donort találni sem a hazai, sem a nemzetközi regiszterekben. Ennek oka a cigányok különleges, eltérő populációs HLA-polimorfizmusa. Így a cigány leukémiás betegek csontvelő-átültetési esélye sokkal kisebb, mint a magyar vagy más európai populációkban élő betegeké.

\section{A NAS-MADO NEMZETKÖZI KUTATÁSI PROGRAM CÉLJA ÉS EREDMÉNYEI}

Az európai csontvelö-transzplantációs aktivitás fokozódásával és a csontvelő donor regiszterek növekedésével kapcsolatban merült fel az európai populációs genetikai adatok vizsgálata, miután több esetben Európa-szerte sikertelen volt a donorkeresés. Ennek oka pedig az, hogy az európai lakosság különböző etnikai, nyelvi, kulturális és vallási csoportok keveréke, ami növelte az európai HLA-polimorfizmus változatosságát. Ritka HLA-fenotípusokat találtak különösen azokban az országokban, melyekben kevert populációk éltek, például Cipruson, Görögországban, Szlovákiában, Lengyelországban és Magyarországon, és melyek a regiszterek donorjainak kb. $20 \%$-át adták, szemben például Hollandiával vagy Svédországgal, ahol ezek aránya a regiszterekben csak 5\% körüli volt. Ugyanakkor egyes kissebségek, mint például a romák HLA-típusai egyáltalán nem voltak reprezentálva a regiszterekben. A 90 -es években ezért széles körü kutatási program indult az európai csontvelö donor regiszterek populációs HLA-típus heterogenitásának felmérésére Anna Cambon-Thomsen (Toulouse) koordinálásával. A MADO (MArrow-DOnor) program egyik részfeladata a NAS-felmérés volt (Newly Assotiated Societies), melyet Magyarország vezetett azzal a feladattal, hogy a HLA-vizsgálatokat a kelet-közép-európai országokban koordinálja. A cél az volt, hogy új donorok toborzásával növeljék a donorkeresés esélyeit a ritka HLA-fenotípussal rendelkező populációkban (Petrányi et al., 2006).

A NAS-országokban több ezer, részben a donorbankokban regisztrált személy és célzottan egyes etnikai csoportokat reprezentáló személyek HLA-tipizálását 
az új molekuláris genetikai és a standard szerológiai módszerekkel végezték. Az egyes populációk HLA-A, -B, -C és -DR lokuszok antigénjeinek gyakoriságát egy központi számítógépes programmal határozták meg. Az eredményeket az egyes országok vonatkozásában az 1. táblázat mutatja be.

1. táblázat. HLA I és II osztályú antigének populációs gyakorisága a kelet-európai régióban

\begin{tabular}{|l|l|l|}
\hline \multicolumn{1}{|c|}{ Populáció } & \multicolumn{1}{|c|}{ Magas gyakoriság } & \multicolumn{1}{c|}{ Alacsony gyakoriság } \\
\hline magyar & $\mathrm{A} 9, \mathrm{Cw} 4 \mathrm{Cw} 5, \mathrm{DRB} 1 * 1101, \mathrm{DRB} 1 * 0301$ & $\mathrm{~A} 28, \mathrm{~B} 15$ \\
cseh & $\mathrm{B} 21, \mathrm{Cw} 6, \mathrm{DRB} 1 * 1401$ & $\mathrm{~A} 9, \mathrm{~A} 11, \mathrm{~B} 35 \mathrm{Cw} 3$ \\
horvát & $\mathrm{A} 10,028, \mathrm{~B} 5, \mathrm{Cw} 1$ & $\mathrm{~A} 2, \mathrm{~B} 15, \mathrm{~B} 21, \mathrm{Cw} 2, \mathrm{Cw} 3$ \\
szlovén & $\mathrm{C}$ 7,DQB1*0502 & $\mathrm{A} 1$ \\
\hline $\begin{array}{l}\text { lengyel } \\
\text { román }\end{array}$ & $\mathrm{DQB} 1 * 0602$ & $\mathrm{DQB} 1 * 0503,{ }_{0} 0502$ \\
cigány & $\mathrm{A} 19, \mathrm{~A} 11, \mathrm{~B} 35, \mathrm{~B} 18$ & $\mathrm{DRB} 1 * 1601$ \\
\hline
\end{tabular}

Az adatok világosan mutatják, hogy a környező országokban az egyes leggyakoribb és legalacsonyabb előfordulású HLA-antigének teljesen eltérőek a magyar, cseh, szlovén, lengyel és román populációkban (Sanches-Mazas et al., 2013). Mivel a vizsgált cigányokban az antigének gyakorisága még feltűnőbb különbséget mutatott, az egy kromoszómán elhelyezkedő HLA-antigénpárokat, a haplotípusokat (melyek a donor recipiens párok egyeztetésénél alapvetően fontosak) külön meghatározták a magyar és cigány populációkban. A két populáció kiemelt leggyakoribb haplotípusai a magyaroknál hasonlóak az Európa közép-keleti régiójában megfigyeltekkel, a cigányoké viszont eltér (Inotai et al., 2015). A cigányokra vonatkozó adatokat összehasonlították a Világ Csontvelö Donor Bank (WBMDR) adataival. A 2. táblázatban rögzített eredmények alapján megállapítható, hogy a roma haplotípusok gyakorisága kiemelkedően nagy eltéréseket mutat a WBMDR-ben megfigyelt gyakoriságokhoz viszonyítva. Ez azt jelenti, hogy a cigányok HLA-fenotípusa minden egyéb népességétöl eltér. Már ebböl is lehet következtetni arra, hogy a roma csontvelő-transzplantációra váró betegek esélye a megfelelő donor megtalálására csak akkor lehetséges, ha a csontvelő-regiszterekbe nagy számban reprezentáltak a roma donorok. A NAS-MADO-program fő céljának megfelelően, közel ezer cigány donort tudtak tipizálni, és a Magyar Donor Bankba regisztrálni (Rajczy et al., 2004). 
2. táblázat. A cigány donorok haplotípus-gyakorisága összehasonlítva a Világ Csontvelő Donor Regiszter (Donor Bank) adataival

\begin{tabular}{|l|c|c|c|c|c|}
\hline HLA & A & B & DR & \multicolumn{1}{|c|}{ Megjegyzés } & Gyakoriság \% \\
\hline HLA & 1 & 17 & 3 & $60 \times$ gyakoribb !!! & 11,5 \\
HLA & 1 & 40 & 6 & $30 \times$ gyakoribb!! & 9,2 \\
HLA & 2 & 52 & 15 & $5 \times$ gyakoribb & 9,7 \\
HLA & 19 & 27 & 2 & $50 \times$ gyakoribb!! & 5,4 \\
HLA & 11 & 5 & 2 & $4 \times$ gyakoribb & 4,1 \\
HLA & 11 & 35 & 7 & $20 \times$ gyakoribb !! & 4,1 \\
\hline HLA & 11 & 21 & 5 & $30 \times$ gyakoribb !! & 2,7 \\
HLA & 9 & 40 & 6 & $2 \times$ gyakoribb & 2,3 \\
HLA & 1 & 8 & 2 & $3 \times$ gyakoribb & 2,0 \\
HLA & 2 & 41 & 3 & $3 \times$ gyakoribb & 2,0 \\
\hline
\end{tabular}

\section{A CIGÁNY CSONTVELŐDONOR-TOBORZÁS TAPASZTALATAI ÉS EREDMÉNYEI}

A kilencvenes években a politikai és szociológiai szemlélet miatt a hazai roma populáció személyein nehezen lehetett vérből vizsgálatokat végezni, mert mind a cigányok, mind a hatóság tartott a genetikai megbélyegzés lehetőségétöl. Ezért fontos volt meggyőzni elsősorban a hatóságokat, hogy ez a vizsgálat nemzetközi program keretében történik, és célja a roma „halálos vérrák” betegség gyógyítási lehetőségeinek elősegítése. A hivatalos és az etikai engedélyek megszerzését követően a donorok szervezése és a vérvételek lebonyolítása az Országos Vérellátó Szolgálat regionális központjainak közremüködésével valósult meg. A donorok toborzásában a helyi Vöröskereszt munkatársai és intézményei is részt vettek, továbbá nagyon fontos volt az egyes községekben a polgármesteri hivatal és a cigány közösségek vezetőinek megnyerése és támogatása. Az egyes helyeken lebonyolított vérvételeket és az új donorok beiktatását a regiszterbe mindig összekötötték felvilágosító előadásokkal, orvosi vizsgálatokkal, kisebb, praktikus ajándékok szétosztásával (pólók, mosószerek, csokoládé stb.). Ezeket az eseményeket a körzeti orvosok, a roma képviselők és a helyi lakosság pozitív hozzáállásának támogatása kísérte. A toborzások az ország két régiójában történtek (Hajdú-Bihar és Baranya megyékben), ahol a legtöbb roma élt. Ennek eredményeként hazánkban hatszáz roma donorral gazdagodott a Magyar Csontvelő Donor Regiszter. Ez az eredmény az európai regiszterek számára is 
fontos volt, hiszen jelentős számban élnek cigányok az egyes európai országokban, ahová az 1400-as, 1600-as években vándoroltak ki, továbbá olyan toborzási gyakorlathoz jutottak hozzá, mely megkönnyítette a kisebbségek toborzását az egyes regiszterekbe.

A romák regiszterbe való bevonásának hamarosan a gyakorlati jelentősége is megmutatkozott. Egy fehérvérüségben szenvedő cigány gyermek, aki csontvelö-átültetésre szorult, és akinek a Világ Csontvelő Donor Regiszterében sehol sem lehetett megfelelő donort találni, egy újonnan regisztrált cigány személy révén olyan donort talált, aki alkalmas volt csontvelö-adásra. A program lebonyolítása során az egyik legfontosabb tapasztalat az volt, hogy a hátrányos helyzetben élö és szociális, valamint kulturális tekintetben elmaradt cigány társadalom magatartását és közremüködését, felzárkóztatását odafigyeléssel és megfelelő hozzáállással nagymértékben elő lehet segíteni egészségügyi vonatkozásban. Ennek fontosságát és első példáját az 1900-as évek második felében József föherceg mutatta meg, akinek ez irányú tevékenységét tanulságként az alábbiakban érintjük röviden.

\section{JÓZSEF FŐHERCEG, A CIGÁNYOK PÁRTFOGÓJÁNAK PÉLDÁJA ÉS „ÜZENETE"}

A cigányok integrálására irányuló Mária Terézia-féle „Regulatio cigarorum” (1770) eredménytelen rendelet volt, mely a cigány szó használatát és a cigányok közötti házasságot is tiltotta. A 19. században, Lotaringiai József Károly föherceg (1833-1905) alcsúti birtokán a cigány családokat pártfogásába vette, szociális, valamint kulturális helyzetüket javította, azon fáradozott, hogy visszaadja őket önmaguknak és a társadalomnak. Együtt élt velük, maga is cigánynak érezte magát, amiképp a cigányok is annak tartották. Megtanította őket becsületesen élni és dolgozni. Pártfogoltjai elsajátítottak hagyományos mezőgazdasági és kisipari ismereteket, munkájukért bért kaptak, nyugodtan és boldogan élhettek. A főherceg nagy szenvedéllyel gondozta az alcsúti arborétumot, ahol botanikai kutatásokat is végzett, és ahol a cigányok rendszeresen munkát kaptak. Iskolát is nyitott számukra, ahol a fiúkat papok, a lányokat az alcsúti apácák tanították. Jó zenei érzékének köszönhetően énekelte dalaikat, és beállt cigányai közé zenélni. A lányoknak hozományt adott, sok esküvőn ő volt a násznagy. Szeretett magyarjai és kedves cigányai mindnyájan keresztapjukként, sőt ,atyjukként” tisztelték. József főherceg romológiai kutatásai és reformjai a cigányság társadalmi-kulturális beilleszkedését szolgálták. Az általa írt első cigány-magyar szótár és a cigány nyelvtan az MTA kiadásában az 1880-as években jelent meg. Egyik kezdeményezöje és föszerkesztője volt Az Osztrák-Magyar Monarchia Írásban és Képben (URL3) címü földrajzi és néprajzi kiadványsorozatnak. Számos külföldi és hazai elismerésben részesült (URL4). 
József föherceg legfőbb érdeme, hogy nyomatékosan felhívta kora közvéleményének figyelmét a cigányság sanyarú helyzetére, elmaradottságára, társadalmi kivetettségére. Embersége, jóindulatú segítőkészsége, anyagi áldozatai, tudományos kutatásai szolgáljanak ma is jó példaként a kormányok és mindazok számára, akik a cigányság szociális és szellemi felemelését alapvetően fontosnak és kívánatosnak tartják.

\section{KÖSZÖNETNYILVÁNÍTÁS}

Anne Cambon-Thomsen NAS-MADO projekt koordinátori tevékenységének, Gyódi Éva, Rajczy Katalin közremüködő munkatársaknak.

\section{IRODALOM}

Gahrton, G. - van Rood, J. - Oudshoorn, M. (2003): The World Marrow Donor Association (WMDA): Its Goals and Activities. Bone Marrow Transplant, 32, 2, 121-128. DOI: 10.1038/ sj.bmt.1704097, https://www.nature.com/articles/1704097

Gyódi E. - Rajczy K. - Pénzes M. et al. (1998): Hungarian Bone Marrow Donor Registry: Present Status and Activity. Bone Marrow Transplantation, Suppl. 4, 38-40.

Gyódi E. - Tauszik T. - Petrány Gy. et al. (1981): The HLA Antigen Distribution in the Gipsy Population in Hungary. Tissue Antigens, 18, 1-12. DOI: 10.1111/j.1399-0039.1981.tb01355.x

Inotai G. - Szilvasi A. - Benko S. et al. (2015): HLA Genetic Diversity in Hungarians and Hungarian Gypsies: Complementary Differentiation Patterns and Demographic Signals Revealed by HLA-A, -B and -DRB1 in Central Europe. Tissue Antigens. Immune Response Genetics, 86, 2 , 115-121, DOI: 10.1111/tan.12600, https://bit.ly/21ZqpCI

Kiszely I. (2004): A magyarság DNS vizsgálatáról. In: Kiszely I.: A magyar ember. II. 776-785. Budapest: Püski Kiadó

KSH (2015): A hazai nemzetiségek demográfiai jellemzői. Statisztikai Tükör, 2015/82, http:// www.ksh.hu/docs/hun/xftp/stattukor/nemzetiseg_demografia.pdf

Pénzes J. - Tátrai P. - Pásztor I. (2018): A roma népesség területi megoszlásának változása Magyarországon az elmúlt évtizedekben. Területi Statisztika, 58, 3-26. DOI: 10.15196/TS580101, http://www.ksh.hu/docs/hun/xftp/terstat/2018/01/ts580101.pdf

Petrányi Gy. - Gyódi É. (2005): A fő hisztokompatibilitási rendszer (MHC) molekuláris genetikai szerepe a „saját és idegen” felismerésben és jelentősége a fajfejlődésben. Magyar Tudomány, 166, 6, 659-670. http://www.matud.iif.hu/05jun/05.html

Petrányi Gy. - Rásonyi R. - Dobos Á. et al. (2006): Involvement of the Newly Associated States in the $5^{\text {th }}$ Framework Program of the European Comission - MADO Project as an Example. Chapter 4. 33-38. In: Lange A. (ed.): Standardisation of Donor-Recipient Matching. Nova Science Publishers, Inc.

Rajczy K. - Gourraud, P. - Pozsonyi E. et al. (2004): The Importance of Inclusion of Ethnic Minorities to Hematopoietic Stem Cell Donor Registry in Hungary. Tissue Antigens, 64, 4, 369-373.

Rajczy K. - Jaini R. - Keresztury L. et al. (2001): Population Expression of HLA*02 Subtypes Indicates a Common Origin for North Indians and Hungarian Gypsies. European Journal of Immunogenetics, 28, 279-281. 
Sanchez-Mazas, A. - Buhler, S. - Nunes, J. M. (2013): A New HLA Map of Europe: Regional Genetic Variation and Its Implication for Peopling History, Disease-association Studies and Tissue Transplantation. Human Hereditary, 76, 162-77. DOI: 10.1159/000360855, https://www. karger.com/Article/Pdf/360855

URL1: Magyarország nemzetiségei. https://hu.wikipedia.org/wiki/Magyarorsz\%C3\%A1g_n\% C3\%A9pess\%C3\%A9ge

URL2: Bencsik G.: Cigányokról: oláh, beás, kárpáti, romungró. https://ciganyokrol.blog. $\mathrm{hu} / 2011 / 04 / 11 /$ olah_beas_karpati_romungro

URL3: Az Osztrák-Magyar Monarchia Írásban és Képben. https://www.tankonyvtar.hu/hu/tartalom/tkt/osztrak-magyar/adatok.html

URL4: Habsburg-Lotaringiai József Károly föherceg. https://hu.wikipedia.org/wiki/Habsburg\% E2\%80\%93Lotaringiai_J\%C3\%B3zsef_K\%C3\%A1roly_f\%C5\%91herceg 